\title{
Scenario of Genotoxicity in Fishes and Its Impact on Fish Industry
}

\author{
M. I. Mir ${ }^{1,3}$, Salma Khan ${ }^{1}$, S. A. Bhat ${ }^{2}$, Ahmad Arif Reshi ${ }^{2}$, F.A Shah ${ }^{3}$, \\ M.H. Balki ${ }^{3}$, Rusheeba Manzoor ${ }^{3}$ \\ ${ }^{I}$ Department of Biological Sciences, R.D.V.V. Jabalpur, MP. \\ ${ }^{2}$ Division of Vety. Biochemistry F.V.Sc \& AH, SKUAST-K, Shuhama, Alustang, Kashmir. \\ ${ }^{3}$ Fo.Fy.Sc, SKUAST-K, Rangil, Gandarbal, Kashmir.
}

\begin{abstract}
Genotoxicity is a property possessed by some substances that makes them harmful to the genetic information contained in organisms. Heavy metal ions and polycyclic hydrocarbons are the most influencing genotoxicants for fishes. A large proportion of genotoxicants are disposed in free flowing water bodies and the funa particulary, fishes are highly affected. Accumulation of genotxicants not only effects the growth of fishes but also decrease the fecundity capacity. Liver and kidney are two important organs affected as enzymes like $M T$ and ALT are playing pivotal role in detoxification of genotoxicants. Genotoxicants have pronounced influence on liver histology and biochemistry which resulted in structural damage to the vital organ. Screening and development of microbial strains and phytoplankton as bioaccumulating agents will help in decreasing pronounce of toxins leading to genetic material damage. The second level effect of genotoxins can be carcinogens, or cancer-causing agents, mutagens, or mutation-causing agents, or teratogens, birth defectcausing agents.
\end{abstract}

Keywords: Genotoxicity, DNA, RNA, MT, ALT, Teratogens.

\section{Introduction}

The importance of the fisheries sector has been highlighted as a major food source. As an important activity allied to agriculture, it strengthens the productive base of agricultural economy and generates selfemployment. Fish makes a vital contribution to the survival and health of a significant portion of the world's population. Fish is especially important in the developing world. In some of Asia's poorest countries (Bangladesh, Cambodia) people derive as much as $75 \%$ of their daily protein from fish. In West Africa fish accounts for $30 \%$ of animal protein intake, and this number would be larger if the poor could afford to buy more. Fish provides essential nourishment, especially quality proteins and fats (macronutrients), vitamins and minerals (micronutrients). Second, for those involved in fisheries, aquaculture and fish trade, fish is a source of income which can be used to purchase other additional food items. The fish industry has been threatened by natural and human activities.

Aquatic ecosystems are continuously loaded with anthropogenic pollutants of which heavy metal ions, microbial toxins, and polycyclic aromatic hydrocarbons form an important group of concern. These pollutants are affecting stages of the aquatic food chain which may lead to the disturbance of the whole ecosystem. Fish can accumulate these pollutants from the dissolved water phase but also from the sediments and food.

Genotoxicity is a deleterious action, which affects a cells genetic material affecting its integrity (WHO, 1997; Environ Health Perspect, 1996). Genotoxic pollution of aquatic ecosystem describes the introduction of contaminants with mutagenic, tertogenic and/or carcinogenic potentials into its principal media and genome of the resident organisms (Environ Health Perspect, 1996; Fagr et al., 2008; Badr and El-Dib, 1978). These contaminants include certain chemical compounds like heavy metals (Matsumoto et al., 2005; Matsumoto, 2003; Pruski and Dixon, 2002) microbial toxins (Environ Health Perspect, 1996) and polycyclic aromatic hydrocarbons (PAHs) (IARC, 1983; Santodonato et al., 1981; Black et al., 1983; Germain et al., 1993). These genotoxicants have been reported to cause mutations because they form strong covalent bonds with DNA, resulting in the formation of DNA adducts preventing accurate replication (Hartwell et al., 2000). Genotoxins affecting germ cells (sperm and egg cells) can pass genetic changes down to descendants (Hartwell et al., 2000) and have been implicated to be against sustainable development principles by WHO $(1997 ; 2002 \mathrm{~b})$ portraying them as significant factors in congenital anomalies, which account for 589,000 deaths in human annually.

\section{Fish as a model for aquatic genotoxicology}

Aquatic animals especially fishes are most susceptible to genotoxic effects caused by the pollutants usually agricultural wastes, chemicals, heavy metals etc. The selection of fishes as a model in the ecogenotoxicological studies could be made since fish is a very sensitive bio-indicator of water quality and can highlight the potential danger of new chemicals introduced in the aquatic environment (Bailey et al., 1992) and 
also respond to toxicants in a manner similar to higher vertebrates (Al-Sabti and Metcalfe, 1995). They have greater ability to metabolize xenobiotics and accumulate pollutants (Grisolia and Corderio, 2000). They are capable of inhabiting practically all zones of the aquatic habitat and have great commercial and recreational value (Solbe, 1993). They play different roles in the tropic web such as undergoing bioaccumulation of environmental pollutants and biotransformation of xenobiotics through cytochrome 450-dependent oxidative metabolism like mammals, besides they respond to mutagens at low concentrations (Gksoyr et al., 1991).

Fish cells retain important traits of fish e.g., poikilothermic behavior, unique xenobiotic metabolism and low rate of repair mechanism (Behls and Senger, 2001). In addition, as compared to mammalian cells, they have been shown to be more sensitive for the induction of DNA damage (Raisuddin and Jha, 2004). Further, the DNA repair has been reported to be slower in fishes than that of mammals (Walton et al., 1984; Maccubbin, 1994; Espina et al., 1997). Therefore, they can be used as a sentinel organism for bio-monitoring studies (Landolt and Kocan, 1983). Therefore, efforts should be made to utilize assays for detecting genotoxicity caused by aquatic pollutants in fishes at DNA level. This will help in formulating long term strategies for fish conservation programme besides estimating a safe level of pollutants in water.

\section{Genotoxicity due to heavy metals}

Aquatic ecosystems receive a number of toxic substances, among which heavy metals released from domestic, industrial and other man-made activities are of significant importance, due to their toxicity, their bioaccumulation potential and their ability to induce damage in DNA. Heavy metal contamination has devastating effects on the ecological balance of the recipient environment and a diversity of aquatic organisms (Ashraj, 2005; Vosyliene and Jankaite, 2006). Among animal species, fishes are the inhabitants that cannot escape from the detrimental effects of these pollutants (Olaifa et al., 2004). Fish are often used as sentinel organisms due to their role in food webs, their potential for bioaccumulation of toxic substances, and their sensitivity to even low concentrations of mutagens (Višnjić-Jeftić et al., 2010; Jarić et al., 2011). The studies carried out on various fishes have shown that these metals alter the physiological activities and biochemical parameters both in tissues and blood (Basa et al., 2003). The mercury toxicity for Clarias batrachus resulted in marked decrease in hemoglobin and erythrocyte count (Salma khan et al.,1992).

Javed and Usmani (2011) investigated the accumulation of heavy metals $(\mathrm{Cu}, \mathrm{Ni}, \mathrm{Fe}, \mathrm{Co}, \mathrm{Mn}, \mathrm{Cr}$ and $\mathrm{Zn}$ ) in three commercially important fishes namely Channa punctatus (murrel), Clarias gariepinus (cat fish) and Labeo rohita (carp). The accumulation was observed in tissues of muscles, liver, kidney, gills, and Integument. The results revealed that the $\mathrm{Fe}$ and $\mathrm{Zn}$ concentrations were the highest in all tissues analysed, followed by $\mathrm{Ni}$, $\mathrm{Cu}, \mathrm{Co}, \mathrm{Mn}$ and $\mathrm{Cr}$ in almost all the three species. In the muscles of Channa punctatus the order of accumulation is $\mathrm{Fe}>\mathrm{Zn}>\mathrm{Ni}>\mathrm{Cu}>\mathrm{Co}>\mathrm{Mn}$, whereas in Clarias gariepinus it was $\mathrm{Fe}>\mathrm{Zn}>\mathrm{Ni}>\mathrm{Cu}=\mathrm{Mn}>\mathrm{Co}>\mathrm{Cr}$. In Labeo rohita the pattern of accumulation was $\mathrm{Zn}>\mathrm{Fe}>\mathrm{Ni}>\mathrm{Cu}>\mathrm{Co}>\mathrm{Mn}$. The order of accumulation of heavy metals was similar in murrel and cat fish. In general, it has been reported that the least accumulation is in muscles while the highest is in kidney. Therefore, these fishes are not fit for consumption. Salma khan et al. (2001) found that cadmium toxicity brought significant decrease of protein fractionate in Clarias batrachus due to the exposure of different concentrations of intoxicants.

Karolina et al. (2012) studied the heavy metal accumulation and the genotoxic effects of 16 trace elements ( $\mathrm{Al}, \mathrm{As}, \mathrm{B}, \mathrm{Ba}, \mathrm{Cd}, \mathrm{Co}, \mathrm{Cr}, \mathrm{Cu}, \mathrm{Fe}, \mathrm{Li}, \mathrm{Mn}, \mathrm{Mo}, \mathrm{Ni}, \mathrm{Pb}, \mathrm{Sr}$, and $\mathrm{Zn}$ ) in different barbel (Barbus barbus) tissues with the alkaline comet assay to monitor the Danube river pollution. They analysed the highest concentrations of $\mathrm{Sr}, \mathrm{Mn}, \mathrm{Fe}, \mathrm{Ba}, \mathrm{B}$, and $\mathrm{Al}$ in gills, $\mathrm{Mo}$ and $\mathrm{Cu}$ in liver, and $\mathrm{As}$ and $\mathrm{Zn}$ in gonads. Concentrations of $\mathrm{Zn}$ and Fe were above maximum acceptable concentrations (MACs) in a number of gonad, gill, and liver samples. Studies of Bagdonas and Vosyliene (2006) and Obiakor et al. (2010b) revealed that even a short-term exposure of fish to $\mathrm{Cu}$ and $\mathrm{Zn}$ in concentrations higher than those prescribed as MAC could produce genotoxic effects on erythrocytes. They compared the comet parameters of the fish from the Danube River with those from Uvac reservoir, Special Nature Reserve, as a control site with a very low anthropogenic influence. They observed differences between the three and five year fish, with significant differences in two of the three assessed parameters (tail moment and tail intensity), which is in accordance with previous studies (Akcha et al., 2004). All three parameters showed significant differences when the studied site and the reference site were compared. The tail intensity in fish from the Danube River $(7.92)$ was significantly higher $(\mathrm{P}<0.001)$ than in fish from the reference site (4.76). Furthermore, the tail moment and the tail length parameters in fish from the Danube river $(1.28$ and 28.51 , resp.) were both significantly higher $(\mathrm{P}=0)$ than in fish from the reference site ( 0.31 and 12.80 , resp.). Marcon et al. (2010) found that a high content of certain metals in the water could be one of the factors that might cause genetic damages in fish. The comet assay has been successfully used to investigate effects of genotoxic pollutants on the integrity of DNA (Çok et al., 2011; Ferraro et al., 2004; Scalon et al., 2010). Micronucleus test was the only genotoxicity test applied thus far on barbel specimens from the natural population in the Danube River (Boettcher et al., 2010). Therefore, the 
present study represents the first application of the comet assay for the evaluation of the Danube river water genotoxicity on barbel.

Venkatramreddy and Paul (2010) showed experimentally that hexavalent chromium (Cr (VI)) can induce oxidative stress (OS) in fish and impair their health due to its redox potential. They investigated liver and kidney tissues of goldfish exposed to different concentrations of $\mathrm{Cr}$ (VI) (LC12.5, LC25 and LC50) following 96h static renewal bioassay. The results of this study clearly show that the fish experienced OS as characterized by significant modulation of the activities of anti-oxidants, such as catalase (CAT), superoxide dismutase (SOD), metallothioneins (MT) and glutathione related enzymes, induction of DNA damage and microscopic morphological changes in the liver and kidney. There was a concentration-dependent increase in percentage of DNA damage with chemical exposure. In the liver, the DNA damage of LC50 treatment group was significantly different from the control group. In the kidney, the DNA damage of LC50 and LC25 were significantly different from the control. Both organs showed a concentration-dependent increase in percentage of DNA damage. In both tissues, CAT activity was decreased whereas SOD activity and hydro-peroxide levels were increased. In addition, GPx activity also increased significantly in higher test concentrations, especially in the kidney.

Hexavalent chromium, a known carcinogen, exerts genotoxic effects in addition to endocrine disruption in freshwater fishes. For example, the physiologic and genetic responses of the European eel (Anguilla anguilla) upon short-term exposure to chromium revealed genotoxic effects (Teles et al., 2005). Biomarkers for endocrine function like plasma cortisol, thyroid stimulating hormone (TSH), free triiodothyronine (T3), and free thyroxin (T4) were determined. The genotoxicity was scored by the frequency of erythrocytic nuclear abnormalities (ENA).

The genotoxic effect of $\mathrm{Cr}$ (III) was studied using fish MN analysis in peripheral blood erythrocytes from Pimephales promelas, the fathead minnow (De-Lemos et al., 2001). The authors used 45 to 60 day-old fish to assess the spontaneity of genetic damage. The genotoxic effect of $\mathrm{Cr}$ (VI) in experiments performed for 7, 14, and 21-d exposure periods was estimated. Significant micro-nucleated erythrocytes (MNE) induction was detected in fish exposed for $7 \mathrm{~d}$ to $2.5 \mathrm{mg} \mathrm{L}-1 \mathrm{Cr}(\mathrm{VI})$, and this trend decreased after $21 \mathrm{~d}$ of exposure. The study reported basal levels of MNE providing laboratory values for future assay quality control.

Trivalent chromium can alter gene expression in the mummichog, Fundulus heteroclitus (Maples and Bain, 2004). The authors examined altered gene expression both in laboratory-exposed fish and in those collected from a Cr-polluted estuarine site and found differential expression of 20 genes from either group of fish. Several genes were highly homologous to known sequences, including a fatty acid-binding protein (FABP), cytochrome $\mathrm{P} 4502 \mathrm{~N} 2$ (CYP2N2), and a precursor to the translation initiation factor eIF2B. Verification of the differentially expressed genes by real-time polymerase chain reaction (PCR) revealed that FABP was repressed to a 3.6-times greater extent (3.6-fold) in the field-site animals than in a reference site, eIF2B was repressed 2-fold, and an expressed sequence tag (EST) termed A31 was induced 2.6-fold. In laboratory-exposed animals, A31 was also induced between 2- and 4- fold. In contrast to the field-site fish, FABP was up-regulated in Cr-exposed animals. The authors envisage using A31 as a biomarker for ascertaining the genotoxic impact of chromium to fish.

Nuclear abnormalities were reported in Oreochromis niloticus exposed to petroleum refinery or $\mathrm{Cr}$ processing plant effluents. This study revealed that although both effluents had genotoxic potential on the fish, the frequencies of lobed nuclei (LN), blebbed nuclei (BL), and notched nuclei (NT) were not significant (Cavas and Ergene-Gozukara, 2005). Similar results were also reported in C. carpio (Zhu et al., 2004). On the other hand, Pimephales promelas exposed to different concentrations ofchromium viz., 1.0, 1.5, 2.0, $2.5 \mathrm{mg} \mathrm{L}-1$ for different exposure times $(7,14,21$ days) demonstrated significant induction of micronuclei (MN) at the $2.5 \mathrm{mg}$ L-1 concentration after 7 days exposure (De-Lemos et al., 2001). Nuclear abnormalities other than MN were evaluated on erythrocytes to assess the genetic damage. This study demonstrated that both effluents are genotoxic, and the level of genetic damage induced by petroleum refinery effluent was relatively higher than the Cr-processing plant effluent. The results further indicate that nuclear abnormalities other than MN, such as BN and LN, could also be used as biomarkers of genotoxic damage.

The differential expression of genes can be used as a biomarker to identify the type of toxicant and the health of fish. For instance, the Cr (VI) treatment of winter flounder (Pseudopleuronectes americanus) revealed alterations in ion-selenium glutathione peroxidases (Chapman, 2004). In this study, 29 differentially expressed genes products were sequenced and identified, substantiating that $\mathrm{Cr}$ (VI) significantly changes gene expression, including two potential glutathione peroxidases in the fish.

The erythrocyte micronucleus test has been used with different fish species to monitor aquatic pollutants displaying mutagenic features in developed countries (Saotome and Hayashi, 2003; Pantaleao et al., 2006). Rodrigue et al. (2003) determined the sensitivity of micronucleus test in freshwater fish species for application in field surveys. The author studied three fish species namely: Brown trout (Salmo trutta), European eel (Anguilla anguilla) and European minnow (Phoxinus phoxinus) for their use as in situ pollution biomarker by measuring the micronucleus indices of their renal erythrocytes. They used cyclophosphamide, colchicine and 
cadmium as pollutants to examine their genotoxicity. Cyclophosphamide (CP) is an alkylating agent. It causes alkylation of the purine ring, and as a result, there is miscoding and blockade of DNA replication. The in vitro micronucleus assay has been used to characterize the origin of the micronuclei induced by cyclophosphamide (Fagr et al., 2008).

Obiakor et al. (2010a) reported while working with Synodontis clarias and Tilapia nilotica from freshwater of the Anambra River that micronuclei are easy to visualize in erythrocytes and therefore can be used as a measure of chromosomal aberration. The authors documented the micronuclei rates of these species, validating them as index of cytogenetic damage, monitoring of aquatic genotoxicants and other sublethal concentrations of chemical pollutants. A confirmatory report of monitoring sensitivity of micronucleus was also made on River Oyi, Anambra, Nigeria, a tributary of the Anambra River which has been under drastic pollution stress of its water (Obiakor et al., 2010c). Genotoxic alterations induced by River Oyi were investigated based on the karyomorphological analysis and micronucleus assay in Clarias gariepinus exposed to its water for 10 and 28 days, respectively. A standard control experiment containing groundwater of drinking quality was set up to monitor deviation. Fish exposed to the water had significantly higher $(\mathrm{P}<0.05)$ number of chromosomal aberrations and micronuclei compared to the control fish exposed at the specified period. After exposure of the fish to the River Oyi water for 28 days, significant $(\mathrm{P}<0.05)$ increase in the genotoxic capacity of the water was evidenced. The study further revealed dose and time response relationship and effect (Obiakor et al., 2010c).

Ahmad et al. (2002) studied the effect of pentachlorophenol on fish genome using haematoxylin-eosin technique and discovered that the frequency of micronucleated erythocytes increases with increased time of exposure to pentachlorophenol. Computer image analysis of morphological variations of erythrocyte indicated 1:5 ratios of micronuclei and main nucleus accompanied by a reduction in cell volume by 600 dot units.

Fagr et al. (2008) evaluated micronucleus assay in fish genome as a sensivtive monitor for aquatic pollution using three tilapia species (Oreochromis niloticus, Oreochromis aureus and Tilapia zilli) and Clarias gariepinus from four locations (River Nile, drainage at Abou Homos, Kafr Eldawar and Lake Mariout) that represent different levels of contaminants (Ali and El-Shehawi, 2007) in Egypt. Results reveal that the four fish species represent various degrees of sensitivity in monitoring genetic damage (especially clastogenic effect). This is indicated by variations in averages of the micro nucleated cells among species at various locations. As previously mentioned by Ali and El-Shehawi (2007), these locations display differential environmental stress. Fagr et al. (2008) found that peripheral blood of Clarias gariepinus is very sensitive in formation of micronucleus depending upon the environmental stress, and might be by other factors

Palhares and Grisolia (2002) compared between the micronuclei frequencies of kidney and gill erythrocytes in tilapia fish, following mitomycin $\mathrm{C}$ treatment detecting no significant difference between them. A contrasting observation was recorded by Fagr et al. (2008) that the peripheral blood was more sensitive with higher micronuclei frequencies for the damage induced by the aquatic contaminants (approximately 150\%) compared with kidney erythrocytes while working on several fish species sourced from different locations in Egypt displaying differential environmental stress. Shukla et al. (2007) and Witeska (2003) suggested that waterborne heavy metals, initially bound to the gills as they were in direct contact with ambient medium and the main site of water movement (Shukla et al., 2007) and subsequently deposited in other tissues, might affect the fish, even if toxic agent was removed from the water. Similarly, Obiakor (2010) and Obiakor et al. (2010a) evaluated the genotoxic status of the Anambra River employing two preponderant fish species of the river and possibility of congenital disease outbreak among the resident population using the river by micronucleus assay. The following criteria for MN identification were adopted from Fenech et al. (2003); the diameter of the micronucleus (MN) should be less than one-third of the main nucleus; MN should be separated from or marginally overlap with main nucleus as long as there is clears identification of the nuclear boundary; and MN should have similar staining as the main nucleus. According to the authors, the fish species showed varying degree of micronucleus frequencies in their genome of sampled peripheral (gill) and kidney blood, portraying them to be sensitive with peripheral blood being significantly higher $(\mathrm{P}<0.05)$.

There are some studies to show the genotoxicity of heavy metals on aquatic organisms, such as copper (Guecheva et al., 2001; Arkhipchu and Garanko, 2005) but actual mechanisms of its genotoxicity are poorly discussed (Bagdonas and Vosyliene, 2006). One of the possible paths of copper genotoxicity is induction of oxidative stress and production of DNA damaging reactive oxygen species (Gabbianelli et al., 2003). According to Bagdonas and Vosyliene (2006), little is known about copper $(\mathrm{Cu})$ and zinc $(\mathrm{Zn})$ genotoxicity. These heavy metals have been documented to induce micronuclei formation in aquatic organisms. Gabbianelli et al. (2003) had reported genotoxic effect of copper in erythrocytes of Sparus aurata while Bagdonas and Vosyliene (2006) documented the single and joint action toxicity of copper and zinc to Rainbow trout, a freshwater fish. However, Obiakor et al. (2010b), showed the genotoxicity of copper, zinc and their binary mixture to two species of fish using micronucleus test. The authors, validating the technique revealed the genotoxic effect of these metallic species at short duration and independent of toxicant concentrations. 
Several studies have described the presence of nuclear abnormalities (NA), other than micronuclei, in fish cells exposed to genotoxic substances (Çavas and Ergene-Gözükara, 2005). Toni and Lília (2009) verified the efficiency of the micronucleus assay and nuclear abnormality assay in field and laboratory work, while using erythrocytes of the tropical marine fish Bathygobius soporator as genotoxicity biomarkers. Gill peripheral blood samples were obtained from specimens of Bathygobius soporator. In order to investigate the frequencies of micronuclei and to assess the sensitivity of species, the results were compared with samples taken from the reference site and maintained in the laboratory, and fish treated with cyclophosphamide. As a result they confirmed the usefulness of the erythrocyte micronucleus as a powerful monitoring tool for detecting genotoxic agents in a coastal environment. Micronuclei frequencies proved to be very reliable for testing genotoxicity in studies in situ and in vitro, as it was possible to compare results obtained in the field with those from the laboratory. The present study suggested that nuclear abnormalities are not good indicators for genotoxicity evaluation in field studies, since their frequencies were higher in the negative and positive control groups in relation to the sites and months of collection. It is worth emphasizing that the mechanisms of formation of these nuclear abnormalities are not yet fully understood (Çavas and Ergene, 2003).

Leonardo and Elisabete (2010) used the micronucleus test in fishes to analyse the environmental quality in two estuarine systems, Santos and Cananéia estuaries, under different degree of contamination. They collected 45 fishes from Santos estuary and 24 fishes from Cananeia estuary. The micronuclei were only observed in individuals from Santos estuary (90,000 cells observed), the micronucleus observation reached $0.2 \%$, which is important in a classification of genotoxicity effect in fishes under contaminated environment. On the other hand, the fishes from Cananéia estuary, although in minor number, did not show micronuclei formation in 48,000 cells observed, confirming the low degree of contamination. Azevedo et al. (2009) and Kuniyoshi et al. (2009) did a study in the same sites of this one. They found that the tissues of the fishes from Santos, in general, presented values of some trace elements more elevated than in the tissues of the fishes captured in Cananéia estuary.

CETESB (2009) reported that the coastal water of Baixada Santista, exactly in the Canal da Bertioga, a channel very close to Santos Estuarine System, is harmed by low concentration of dissolved oxygen, enrichment of nutrients and other compounds, the sediments in this place were capable to accumulate pollutants due to the presence by metals, PAHs, nutrients of fecal origin. While in the Cananéia region, more exactly in the Mar de Cananéia, the quality of water did not present significant alteration and the sediments did not present accumulation of any substance. Azevedo (2008) and Oliveira (2007) in similar studies observed low frequency of micronuclei in the erythrocytes of the fishes caught in Santos estuary and Bay and lower yet in Cananéia. Kirschbaum et al. (2009) observed micronuclei frequency in blood cells of Centropomus parallelus, fish species, in Cananéia and São Vicente estuaries. São Vicente estuary is very close to Santos Estuary and is also exposed to several pollutant inputs. They found a frequency of micronuclei higher in São Vicente estuary than in Cananéia. In São Vicente estuary they found frequencies of $0.33 \%$ in winter and $0.13 \%$ in summer; and in Cananéia estuary the frequency of micronuclei was $0.03 \%$ in winter and $0.07 \%$ in summer. In the present study, fishes of genus Centropomus sp. were only caught in Santos. From 8 individuals, 4 present micronuclei in their erythrocytes. Two of them show $0.05 \%$ of frequency of micronucleus, 1 had $0.10 \%$ and the other one $0.20 \%$. Other studies comparing polluted and non-polluted sites [Amado, (2006); Wirzinger (2007)] verified that the fishes from the places nearest of the source of pollution shows bigger frequency of micronuclei in their erythrocytes than that one collected in farthest places.

\section{Genotoxicity due to Microbial Toxins}

Many evidences have indicated that not only mammals are susceptible to cyanotoxins, but fishes as well (Jos et al., 2005). The accumulation in the liver and muscles of T. rendalli was demonstrated by Soares et al. (2004), who also showed that these toxins could still be found in the muscles of the fish several days after contamination The metabolism of microcystins in animals gives rise to the formation of reactive oxygen species, such as superoxide anion radicals, hydrogen peroxide and hydroxyl radicals (Ding et al., 2001). In a species of carp (Carassius auratus gibelio) high mortality occurred when fish were fed on diets containing even low doses of microcystin (1.02-10.76 $\mu \mathrm{g} \mathrm{kg}^{-1} \mathrm{bw}$ ) (Zhao et al., 2005). Zhao et al. (2006) found a consumption of 1500$6000 \mathrm{~g} / \mathrm{kg}$ body weight of microcystin by tilapia to be equivalent to $150-600 \mu \mathrm{g} / \mathrm{kg}$ of body weight injected via ip, without affecting the growth or feeding rate of the species.

Ricardo et al. (2010) evaluated the toxicity and genotoxicity in Astyanax bimaculatus, as induced by an extract of cyanobacterial microcystins, using two administration routes and different endpoints, such as micronucleus and apoptosis-necrosis testing, and comet assaying. They revealed the genotoxicity caused by the microcystins LR and LA from a bloom collected in a eutrophic lake LC50 (72 h) was determined as $242.81 \mu \mathrm{g}$ $\mathrm{L}^{-1}$ and LD50 (72 h) as $49.19 \mu \mathrm{g} \mathrm{kg}^{-1} \mathrm{bw}$. There observed a significant increase of DNA damage in peripheral erythrocytes, following intraperitoneal injection (ip) with tested concentrations of $24.58 \mu^{-10 ~ g^{-1}}$ bw and 36.88 $\mu \mathrm{g} \mathrm{kg}^{-1} \mathrm{bw}$, as well as through body exposure to a concentration of $103.72 \mu \mathrm{g} \mathrm{L}^{-1}$. Micronucleus (MN) induction 
was observed after ip injections of $24.58 \mu \mathrm{g} \mathrm{kg}^{-1}$ bw and $36.88 \mu \mathrm{g} \mathrm{kg}^{-1}$ bw for $72 \mathrm{~h}$, as well as following body exposure for 72 at $103.72 \mu \mathrm{g} \mathrm{L}^{-1}$. Thus, both exposure routes resulted in MN induction and DNA damage. Apoptosis-necrosis testing was carried out only by ip injection with concentrations of $24.58 \mu \mathrm{g} \mathrm{kg}^{-1}$ bw and $36.88 \mu \mathrm{g} \mathrm{kg}^{-1} \mathrm{bw}$. Exposure to microcystins at lower concentrations induced more apoptosis than necrosis in peripheral erythrocytes, whereas exposure at higher concentrations gave rise to both conditions.

Genotoxic effect has been recorded for microcystin LR causing DNA damage and fragmentation. The impact of microcystin LR on early developmental stages of Korean mud loach (Misgurnus mizolepis) was discussed by Liu et al. (2002) who attempted to find a difference in the sensitivity of fish eggs and larvae to microcystin LR. Palikova et al. (2007) studied the genotoxic effect of microcystins and crude extract of cyanobacteria using detection of chromosomal aberrations in the early life stages of weather fish (Misgurnus fossilis). They exposed weather fish eggs at an eye spot stage for 96 hours to semipurified compound of microcystins (MC-LR: $\sum M C=1: 2.6$ ) and crude cyanobacterial extract (MC-LR: $\sum M C=1: 2.1$ ) both at doses of 130,50 and $13 \mathrm{~g} \backslash 1 \mathrm{~L}$. Hatching time in individual groups and aberrations in the behaviour of hatched specimens were recorded. Cytogenetic screening revealed both chromatid (gaps) and chromosomal aberrations (rings, dicentrics), percentage of which increased with the increased concentration of microcystins and the higher doses of crude cyanobacterial extract. The highest number of aberrant metaphases was recorded after the application of the highest concentrations of cyanobacterial extract and microcystin $(\mathrm{p} \leq 0.05)$. Embryo mortality was affected especially by crude cyanobacterial extract, therefore other toxic elements than microcystins present in the extract were probably involved.

\section{Genotoxicity due to Polycyclic Aromatic Hydrocarbons}

PAHs are ubiqitous environmental contaminants derived from incomplete combustion of carbon. In the United States, PAHs as a mixture (\#7), BaP (\#9) and benzo(b)fluroanthene (\#10) are recognized in the top ten on CERCLA's Priority List of Hazardous Substances (http://www.atsdr.cdc.gov/cercla/05list.html). In contrast to halogenated hydrocarbons such as PCBs and chlorinated pesticides which have shown downward trends in US sediment cores, trends in sediment PAH concentrations have been increasing particularly near urban land use (Van Metre \& Mahler, 2005).

Wu Dong et al. (2008) investigated the potential of benzo(a)pyrene (BaP), a representative carcinogenic polycyclic aromatic hydrocarbon $(\mathrm{PAH})$ and fadrozole, a therapeutically used non-steroidal aromatase inhibitor, to affect CYP19A1 and CYP19A2 mRNA expression in Fundulus heteroclitus. By using in situ hybridization and testing effects of exposure at different developmental stages, they aimed to highlight some of the stage and cell-type specific effects of these two compounds on CYP19 mRNA expression. The CYP19A1 expression was significantly decreased after BaP exposure in the 3 month old Fundulus immature oocytes, but $\mathrm{BaP}$ did not affect CYP19A1 expression at any stage in adult oocytes. In embryo brains, BaP significantly decreased CYP19A2 compared to controls by 3.6 -fold at 14 days post-fertilization. In adults, CYP19A2 expression was decreased significantly in the pituitary and hypothalamus ( $81 \%$ and $85 \%$ of controls, respectively). Promoter regions of Fundulus CYP19s were cloned, and putative response elements in the CYP19A1 and CYP19A2 promoters such as CRE, AhR and ERE may be involved in BaP-mediated changes in CYP19 expression. In order to compare the mechanism of BaP-mediated inhibition with that of a known aromatase inhibitor, fish were also exposed to fadrozole $(20$ and $100 \mu \mathrm{g} / \mathrm{L})$. Fadrozole did not significantly decrease the mRNA expression in embryos or adult Fundulus. However, aromatase enzyme activity was significantly decreased in adult ovary and brain tissues.

In various in vitro and in vivo fish systems PAH exposure has resulted in decreased: egg output, ovarian somatic index, 17ß-estradiol levels, and vitellogenin production (Hoffman \& Oris, 2006). Three studies have specifically investigated BaP's effects on fish CYP19A1 and CYP19A2 mRNA expression using RT-PCR with mixed results. In zebra fish (Danio rerio) exposed up to $3 \mu \mathrm{g} / \mathrm{L} \mathrm{BaP}$ for 56 days, CYP19A2 mRNA was increased but no effect on CYP19A1 was observed (Hoffman \& Oris, 2006). Similarly, CYP19A2 induction was found when $17 \mathrm{dpf}$ juvenile zebra fish were exposed for 3 days to $10 \mu \mathrm{M} \mathrm{BaP}(2.5 \mathrm{mg} / \mathrm{L})$ (Kazeto et al., 2004). In contrast, in our previous studies with Fundulus exposed to water borne BaP up to $10 \mu \mathrm{g} / \mathrm{L}$ for 15 days, we did not see a significant effect on expression of either CYP19 message (Patel et al., 2006).

The toxicity of PAHs is a continuing subject of intense investigation (Park et al., 2009). Metabolic activation of PAHs to reactive intermediates and aryl hydrocarbon receptor (AHR)-dependent alterations in gene expression are prominent modes of toxic action. Lawrence et al. (2006) compared and contrasted biomarkers (liver, blood and trunk kidney) for oxidative stress and AHR activation (CYP1A protein and enzymatic activity) after subchronic benzo[a] pyrene $(\mathrm{BaP})$ and benzo[e]pyrene $(\mathrm{BeP})$ treatments of rainbow trout. In the $1-100 \mathrm{nM}$ concentration range benzo[a]pyrene $(\mathrm{BaP})$ but not benzo[e]pyrene $(\mathrm{BeP})$ competitively displaced $2 \mathrm{nM}[(3) \mathrm{H}] 2$, 3, 7, 8-tetrachloro-dibenzo-p-dioxin from rainbow trout AHR2 $\alpha$. Based on appearance of fluorescent aromatic compounds in bile over $3,7,14,28$ or 50 days of feeding $3 \mu \mathrm{g}$ of $\mathrm{BaP}$ or $\mathrm{BeP} / \mathrm{g}$ fish/day, rainbow trout liver readily excreted these polyaromatic hydrocarbons (PAHs) and their metabolites at near steady state rates. 
CYP1A proteins catalyzed more than $98 \%$ of ethoxyresorufin-O-deethylase (EROD) activity in rainbow trout hepatic microsomes. There was a strong positive correlation between hepatic EROD activity and DNA damage in blood cells over time for both PAHs. Neither CYP1A protein nor 3-nitrotyrosine (a biomarker for oxidative stress) immunostaining in trunk kidney were significantly altered by $\mathrm{BaP}$ or $\mathrm{BeP}$ after 3, 7, 14, or 28 days. There was no clear association between AHR2 $\alpha$ affinity and BaP and BeP-induced oxidative stress.

Linda et al. (2011) analysed the levels of polycyclic aromatic hydrocarbons (PAH) in smoked Scomba japonicus sampled from four Ghanaian markets; Ada, Chorkor, Madina and Winneba and labelled ADM, CKM, MDM and WBM respectively. They identified 20 individual PAHs including acenaphthene, acenaphtyelene, anthanthrene, anthracene, benz(a) anthracene, benzo(a)pyrene, benzo(b)fluoranthene, benzo(e) pyrene, benzo(ghi)perylene, benzo(j)fluoranthene, benzo(k) fluoranthene, chrysene, cyclopenta(cd)pyrene, dibenzo(ah)anthracene, fluoranthene, fluorene, indeno(1, 2, 3-cd)pyrene, naphthalene, phenanthrene and pyrene in 34 smoked fish samples using gas chromatographic techniques with flame ionization detector. Individual polycyclic aromatic hydrocarbon concentrations varied from below the limit of detection to $83.928: \mathrm{g} / \mathrm{kg}$. The levels in the samples were in decreasing total mean concentration order of WBM, MDM, CKM and ADM. They observed that sources of polycyclic aromatic hydrocarbon contamination can be multiple and varied.

\section{Assessment of Genotoxicity}

Genetic toxicology is a multidisciplinary field of research involved in detecting compounds capable of causing DNA damage and/or protecting DNA, with the aim of understanding potential biological consequences and molecular mechanisms of genetic material (Uhl et al., 2003).

\section{Chromosomal Aberration Test (CAT)}

The study of DNA damage at the chromosome level is an essential part of genetic toxicology because chromosomal mutation is an important event in carcinogenesis. Different types of chemicals and radiations have been reported to be responsible for production of various types of aberrations in the structure and number of chromosomes. Metal toxicity arises predominantly from the binding of metals to essential biomolecules such as enzymes and transporters and the involvement of certain metals in the formation of radicals (Mason and Jenkins, 1995). Protection against metal toxicity can be achieved by the synthesis of metal binding ligands to sequester the incoming metal ions in less reactive pools, including cytosolic proteins like metallothionein (MT), lysosomes and granules (Vijver et al., 2004). This may also influence the subcellular partitioning of essential and nonessential metals and metal-dependent metabolic functions. It is well known that the induction of MT, as response to elevated levels of waterborne and dietary metal exposure, is one of the first and most important responses to fight metal toxicity. However, metallothioneins are not the only proteins involved in metal binding and it is therefore important to determine which and how much metals are bound to the metallothionein pool in comparison to the other metal binding ligands present. Disturbances in serum ion concentrations, serum alanine aminotransferase activity (ALT), hematocrite and condition factor are indicators of toxic effects and increase in serum ALT concentration is a biomarker of incomplete detoxification of metal ions and level of structural damage of liver. Chromosomal aberrations result from abnormalities in DNA duplication during the S phase; this may be due to the interference of the pollutants with nucleotide synthesis (Mattar et al., 1992), leading to malformation of DNA molecules (Landolt and Kocan, 1983). The chromosomal aberrations also arise as a consequence of miss-repair or of miss-replication of damaged DNA. Also, according to (Natarajan and Obe, 1978), the ultimate lesions responsible for aberration formation are DNA-strand break. So, chromosomal aberration can be used as an indicator of DNA damage. OH radicals and $\mathrm{O} 2$ are considered the most important biologically relevant oxygen species; however they are able to react directly with all kind of cells components including cellular DNA. The oxidative DNA damage introduced by direct reaction of these radicals, leads to aberration on base pairs (Retel et al., 1993). In other studies, Goodale et al., (2008), showed that aquatic chromium is both increased cytotoxic and genotoxic to fish cells. The literature so far reveals that maximum toxicants are accumulated in vital organs such as liver, kidney and heart which resulted in to organ malfunction. The liver is the most important organ for nullifying the oxidative stress by its oxidative enzymes, which resulted in to generation and accumulation of free radicals to greater extent. These free radicals hinder in DNA replication and DNA repair mechanism. By studying the metaphase structure after exposing the organisms to any physical or chemical agents, the clastogenic properties can be detected.

\section{Sister Chromatid Exchanges (SCEs)}

Single chromatid exchange is a DNA replication dependent technique. Sister chromatids come in pairs, consisting of one original chromosome and its identical copy, generated during DNA replication. Many chemicals that cause chromosomal aberration and mutations were found to induce sister chromatid exchanges (SCEs) as well. The assay of SCEs is often found for mutagenicity testing. Such an exchange arises as a consequence of repair process which permits DNA - replication to proceed beyond DNA lesions in the 
replication fork. Thus SCEs represent the interchange of DNA replication products at apparently homologous loci. The exchange process involves DNA breakage and reunion. It is a short term test for detection of reciprocal exchanges of DNA between two sister chromatids of a duplicating chromosome.

\section{Single Cell Gel Electrophoresis (SCGE) or Comet Assay}

The comet assay was developed by Rydberd and Johanson (1978), who were first to perform a quantitative damage of DNA in single cells. Later on, Singh and their co-workers (1988) improved the assay by developing an electrophoretic microgel technique under neutral conditions and stained the DNA with Ethidium Bromide. The comet assay is increasingly used in industrial genotoxicity in vitro. In vitro technologies have been used for determining various end points like DNA damage, cytotoxicity and chromosomal aberration frequencies (Jamil et al., 2004).

It is a simple and sensitive method for studying DNA damage and repair. In this technique a small number of cells suspended in a thin agarose gel on a microscope slide are lysed, electrophoresed and stained with a fluorescent DNA -binding dye. Cells with increased DNA damage display increased migration of chromosomal DNA from the nucleus towards the anode, which resembles the shape of a comet. The assay has manifold applications in fundamental research for DNA damage and repair, in genotoxicity testing of novel chemicals and pharmaceuticals (Hartmann and Speit, 2005).

\section{DNA 3'-OH End Labelling}

The DNA 3'-OH End Labelling is a TUNEL system that measures the fragmented DNA of apoptotic cells by incorporating fluorescein-12-dUTP at the $3^{\prime}-\mathrm{OH}$ ends of the DNA using the enzyme Terminal deoxynucleotidyl Transferase (TdT), which forms a polymeric tail using the principle of the TUNEL (TdTmediated dUTP Nick-End Labelling ) assay. The fluorescein-12-dUTP labelled DNA can then either be visualized directly by fluorescence microscopy or quantities by flow cytometry. This assay is for rapid detection of apoptotic cells in situ at the single cell level or in suspension. This system measures nuclear DNA fragmentations which is an important biochemical hallmark of apoptosis of many cell types (Kapoor and Nagpure, 2005).

\section{DNA Ladder Assay}

The earliest structural change that can be noted during physiological and pathological cell death is a marked condensation of nucleus. In which nuclear chromatin aggregate in dense masses beneath the nuclear envelop so called chromatin condensation. Chromatin condensation, in turn, is associated with a specific type of DNA fragmentation in which DNA is first cleaved into large 300 and $50 \mathrm{~Kb}$ fragments and then subsequently cleaved between nucleosomes to generate fragments of DNA that are multiples of 180 to 200 bp around a histone core. As they are conformationally protected from digestion, this endonuclease mediated nucleosome excision is observable as a DNA ladder by agarose gel electrophoresis. The method involves rapid lysis of cell samples and inactivation of nucleases subsequently isolation and purification of DNA which is being labelled by a fluorescent dye for its visualization after electrophoresis process through UV Trans illuminator.

This characteristic form of DNA degradation is known as major biochemical hallmark especially of PCD (Programmed Cell Death) so this is an optimized system for the purification and visualization of DNA fragments confirming apoptosis (Kapoor and Nagpure, 2005).

\begin{tabular}{|l|l|}
\hline Heavy metals & \multicolumn{1}{|c|}{ Fe, Ni, Co, Cr, Zn, Al, As, B, Ba, Cd, Li, Mo, Pb, Sr, Zn } \\
\hline Microbial toxin & \multicolumn{1}{c|}{ Microcystein } \\
\hline $\begin{array}{l}\text { Poly cyclic aromatic } \\
\text { hydrocarbons }\end{array}$ & $\begin{array}{l}\text { Benzo (b) fluroanthene, cholorinated pesticides, PCB, fadrozole, banzo (e) pyrene, banzo } \\
\text { (a) pyrene, ethoxyresorufin-O- deethylase. Acenaphthene, acenaphtyelene, anthanthrene, } \\
\text { anthracene, benz(a) anthracene, benzo(a)pyrene, benzo(b)fluoranthene, benzo(e) pyrene, } \\
\text { benzo(ghi)perylene, benzo(j)fluoranthene, benzo(k) fluoranthene, chrysene, } \\
\text { cyclopenta(cd)pyrene, dibenzo(ah)anthracene, fluoranthene, fluorene, indeno(1, 2, 3- } \\
\text { cd)pyrene, naphthalene, phenanthrene and pyrene }\end{array}$ \\
\hline
\end{tabular}

Table: list of potent genotoxicants.

\section{Conclusion}

The objective of the present study was to review the genotoxicity in fishes. Fish can serve as an excellent model for the assessment of genotoxicity in aquatic environment under both laboratory and field conditions. Since, they are the vertebrates that can metabolise, concentrate and store the genotoxins. Genotoxic evaluation of aquatic environment is a key mechanism for translating the principle of sustainable development into action. Genotoxic pollutants have been associated with gene mutation (mutagenic) and proliferation of tissue (carcinogenic potential). These chemicals are capable of transforming the future generations if unchecked because of their potential to cause genetic hazards. Though fish die first, next is human. 
From the study it is prominent that micronucleus assay is a simple, powerful monitoring tool for detecting genetic material damage caused by the toxication of genotoxicants, as micronucleus frequencies proved to be very reliable for testing genotoxicity in vitro studies. Besides, Comet assay has many advantages, such as being independent of chromosome number, not requiring animal pre-treatment with BrdU and colchicines, and being less time-consuming due to automatic scoring of comets. The importance of micronucleus assay and comet assay over other available techniques is, because of their high frequency of error rates and complication in experimentation. In case of nuclear abnormality assay, the frequencies are highly variable in the positive and negative groups. While sister chromatid exchange technique is a laborious method, especially in vivo, because it needs dividing cells.

Apart from the techniques, the study shows heavy metals like cadmium, nickel, chromium, lead etc.; microbial toxins like microcystins, nodularins, etc. and a number of polycyclic aromatic hydrocarbons like benz[a]anthracene and chrysene, benzo[b]fluoranthene, benzo[j] fluoranthene, benzo[k]fluoranthene, benzo[a]pyrene, benzo[ghi]perylene, coronene, dibenz(a,h),anthracene (C20H14), indeno(1,2,3-cd)pyrene $(\mathrm{C} 22 \mathrm{H} 12)$ and ovalene are causing genotoxicity in fishes. From the study it has been seen, heavy metals have large contribution for genotoxicity than microbial toxins and polycyclic aromatic hydrocarbons. Because the heavy metal ions are deleterious affecting the chemical oxidation demand and also enhance the growth of bacteria responsible for microbial toxicity. Treat the cause not the symptom should be applied for sustained development and use of biological controls should be encouraged at first line treatments in agri, pharma and other industrial activities. The preliminary studies should be carried out for regulating the disposal of genotoxicants in water bodies most particularly the heavy metal ions and secondly such techniques should be put forth which make them less toxic in terms of their catenation. Besides, such genetic variants should be developed which can effectively decrease the toxicating capacity of genotoxicants. The growth of such aquatic weeds which have high bioaccumulative capacity should be encouraged in water bodies without resulting in the eutrophication of water bodies.

\section{Bibliography}

[1]. Ahmad W., Ali M.N., Farah M.A. and Ateeq B. (2002) Computerized automated morphometric assay including frequency estimation of pentachlorphenol induced nuclear anomalies (micronucleus) in catfish, Heteropneustes fossilis. Chromo., 110 (8): 570-574.

[2]. Akcha F., Leday G. and Pfohl-Leszkowicz A. (2004) Measurement of DNA adducts and strand breaks in dab (Limanda limanda) collected in the field: effects of biotic (age, sex) and abiotic (sampling site and period) factors on the extent of DNA damage. Mutation Research, 552(1-2):197-207.

[3]. Ali F.A. and El-Shehawi A.M. (2007) Estimation of water pollution by genetic biomarkers. In: Al-Sabti, K (1991) Handbook of Genotoxic Effects and Fish Chromosomes. Jozef Stefan Institute, Jamova.

[4]. Al-Sabti K. and Metcalfe C.D. (1995) Fish micronuclei for assessing genotoxicity in water. Mutat. Res., 343: 121-135.

[5]. Amado L.L., Rosa C.E., Leite A.M., Moraes L., Pires W.V. et al. (2006) Biomarkers in croakers Micropogonias furnieri (Teleostei: Sciaenidae) from polluted and non-polluted areas from the Patos Lagoon estuary (Southern Brazil): Evidences of genotoxic and immunological effects". Marine Pollution Bulletin, 52: 199-206 pp.

[6]. Arkhipchu V.V. and Garanko N.N. (2005) Ecotox Environ Saf., 1(62): 42-52.

[7]. Ashraj W. (2005) Accumulation of heavy metals in kidney and heart tissues of Epinephelus micodon fish from the Arabian Gulf. Environmental Monitoring Assessment, 1-3(103): 311- 316.

[8]. Azevedo J.S. (2008) Biomarcadores de contaminação ambiental em Cathorops spixii nos dois Estuários de Santos/São Vicente e Cananéia, São Paulo, Brasil. Tese de Doutorado. Instituto Oceanográfico da Universidade de São Paulo.

[9]. Azevedo J.S., Fernandez W.S., Farias L.A., Fávaro D.I.T. and Braga E.S. (2009) Use of Cathorops spixii as bioindicator of pollution of trace metals in the Santos Bay, Brazil”. Ecotoxicology, 18: 577-588.

[10]. Badr E.A. and El-Dib S.E. (1978) Effects of water pollution on the cell division cycle and chromosome behavior in Tillapia spp. Egypt. J. Genet. Cytol., 7: 193-200.

[11]. Bagdonas E. and Vosyliene M.Z. (2006) A study of toxicity and genotoxicity of copper, zinc and their mixture to rainbow trout (Oncorhynchus mykiss) Biologija., 1: 8-13.

[12]. Bailey E., Crespo S., Nonnotte C., Colino A., Leray L. and Aubree A. (1992) Morphological and functional alterations induced in trout intestine by dietary cadmium and lead. Fish Biology, 28: 69-80.

[13]. Basa, Siraj P. and Usha-Rani A. (2003) Cadmium induced antioxidant defense mechanism in fresh water teleost Oreochromis mossambicus (tilapia). EcoToxicology Environment Safety, 2(56): 218- 221.

[14]. Behls and Senger, (2001) The genotoxic hazards of domestic wastes in surface water .Mutat. Res., 410:223-236.

[15]. Black J.A., Birge W.J., Westerman A.G., Francis P.C. (1983) Comparative aquatic toxicology of aromatic hydrocarbons, Fund. App1. Toxicol., 3: 353-358.

[16]. Boettcher M., Grund S., Keiter S. et al. (2010) Comparison of in vitro and in situ genotoxicity in the Danube River by means of the comet assay and the micronucleus test. Mutation Research, 700(1-2):11-17.

[17]. Çavas T. and Ergene-Gözükara S. (2003) Micronuclei, nuclear lesions and interphase silver-stained nuclear organizer regions (AgNORs) as cyto-genotoxicity indicators in Oreochromis niloticos exposed to textile mill effluent. Mutat Res., 538:87-91.

[18]. Cavas T. and Ergene-Gozukara S. (2005) Induction of micronuclei and nuclear abnormalities in Oreochromis niloticus following exposure to petroleum refinery and chromium processing plant effluents. Aquat Toxicol., 74:264-271.

[19]. Cetesb (São Paulo). (2009) Relatório de Qualidade das Âguas Litorâneas no estado de São Paulo 2008

[20]. Chapman L.M., Roling J.A., Bingham L.K., Herald M.R. and Baldwin W.S. (2004) Construction of a subtractive library from hexavalent chromium treated winter flounder (Pseudopleuronectes americanus) reveals alterations in ion-selenium glutathione peroxidases. Aqua Toxicol., 67:181-194.

[21]. Çok I., Ulutaş O.K., Okuşluk O., Durmaz E. and Demir N. (2011) Evaluation of DNA damage in Common carp (Cyprinus carpio L.) by comet assay for determination of possible pollution in Lake Mogan (Ankara) The Scientific World Journal, 11:1455-1461. 
[22]. De-Lemos C.T., Rodel P.M., Terra N.R. and Erdtman B. (2001) Evaluation of basal micronucleus frequency and hexavalent chromium effects in fish erythrocytes. Environ Toxicol Chem., 20(6):1320-1324.

[23]. Ding W.X., Shen H.M. and Ong C.N. (2001) Critical reactive oxygen species formation in microcystin-induced cytoskeleton disruption in primary cultured hepatocytes. J Toxicol Environ Health, 64: 507-519.

[24]. Environ Health Perspect (1996) The mechanism of benzene-induced leukemia: A hypothesis and speculations on the causes of leukemia, 104 (Suppl 6): pp. 1219-1225.

[25]. Espina S., Vanegas C.S., Bottlo and Villarnieva S. (1997) Acute toxicity and synergism of cadmium and zinc in white shrimp, Penaeus setiferus.Bull. Environ. Contam. Toxical, 58: 87-92.

[26]. Fagr A., El-shehawi A.M. and Seehy M.A. (2008) Micronucleas test in fish genome: A sensitive monitor for aquatic pollution. African Journal of Biotechnology, 7(5): 606-612.

[27]. Fenech M., Chang W.P., Kirsch V.M., Holland N., Bonassi S. and Zeiger E. (2003) Human micronucleus project. Human Project: Detailed description of the scoring criteria for the cytokinesis-block micronucleus assay using isolated human lymphocyte cultures. Mutat. Res., 534 (1-2): 65-75.

[28]. Ferraro M.V.M., Fenocchio A.S., Mantovani M.S., de-Oliveira Ribeiro C. and Cestari M.M. (2004) Mutagenic effects of tributyltin and inorganic lead ( $\mathrm{Pb}$ II) on the fish $\mathrm{H}$. malabaricus as evaluated using the comet assay and the piscine micronucleus and chromosome aberration tests. Genetics and Molecular Biology, 27(1): 103-107.

[29]. Gabbianelli R., Lupid G., Villarini M. and Falcioni G. (2003) Arch Environ Contam Toxicol., 45: 350-6.

[30]. Germain A., Perron F. and Van-Coillie R. (1993) PAHs in the environment: Fate, ecotoxicity and regulations, environment Canada, Conservation and Protection, Quebec Region, Montreal, Que.

[31]. Gksoyr A.,Anderson T., Buhler D.R., Stegeman J.J., Williams D.B. and Forlin L. (1991) Immuno-chemical cross reactivity of $\beta$ naptholavone inducible cytochrome Puso(PuSoIAI) in live microsomes from different fish species and rat. Fish physiol. Chem., 9: $1-13$.

[32]. Grisolia C.K. and Corderio C.M.T. (2000) Variability in micronucleus induction with different mutagens applied to several species of fish. Gene. T Nol. Bios., 23: 235-239.

[33]. Guecheva T., Henriques J.A. and Erdtmann B. (2001) Genotoxic effects of copper sulphate in fresh water Planarian in vivo, studied with single- cell gel test (comet assay). Mutat. Res., 497: 19-27.

[34]. Hartmann A. and Speit G.A. (2005) A comet assay: A sensitive genotoxicity test for the detection of DNA damage and repair. Spinger-Academic Journal, 314: 275-286.

[35]. Hartwell L.H., Hood L., Goldberg M.L., Reynolds A.E., Silver L.M. and Veres R.C. (2000) Genetics: from genes to genomes. Mc Graw Hill Higher Education. ISBN 0-07-540923-2. p. 70-98, 144-169, 179-182, 341-351.

[36]. IARC (1983) Polynuclear Aromatic Compounds, Part 1, Chemical, Environmental and Experimental Data, IARC Monographs on the Evaluation of the Carcinogenic Risk of Chemicals to Humans, 32: 33-91.

[37]. Jamil K., Shaik A.P., Mahboob M. and Krishna D. (2004) Effect of organophosphorus and organochlorine pesticides on human lymphocytes in vitro. Drugs Chem. Toxicol., 27: 133-144.

[38]. Jarić I., Višnjić-Jeftić Ž., Cvijanović G. et al. (2011) Determination of differential heavy metal and trace element accumulation in liver, gills, intestine and muscle of sterlet (Acipenser ruthenus) from the Danube River in Serbia by ICP-OES. Microchemical Journal, 98:77-81.

[39]. Jos A., Pichardo S., Prieto A.I., Repetto G., Vázquez C.M., Moreno I. and Cameán A.M. (2005) Toxic cyanobacterial cells containing microcystins induce oxidative stress in exposed tilapia fish (Oreochromis sp.) under laboratory conditions. Aquat Toxicol., 72: 261-271.

[40]. Kapoor D. and Nagpure N.S. (2005) Training on genotoxic assays in fishes, National Bureau of Fish Genetic Resources Lucknow, pp 56-60.

[41]. Karolina S., Zoran G., Stoimir K., ŽeljkaV.J., Ivan J., Jelena K. V., BrankaV. G., and Mirjana L. (2012) Heavy metal accumulation and the genotoxicity in Barbel (Barbus barbus) as indicators of the Danube river pollution. ScientificWorld Journal, 2012: 351074.

[42]. Kazeto Y., Place A.R. and Trant J.M. (2004) Effects of endocrine disrupting chemicals on the expression of CYP19 genes in zebra fish (Danio rerio) juveniles. Aquat. Toxicol., 69:25-34.

[43]. Kirschbaum A.A., Seriani R., Pereira C.D.S., Assunção A., Rotundo M.M. et al. (2009) Cytogenotoxicity biomarkers in fat sook Centropomus parallelus from Cananéia and São Vicente estuaries, SP, Brazil”. Genetics and Molecular Biology, 32 (1):151-154.

[44]. Kuniyoshi L.S., Fávaro D.I.T. and Braga E.S. (2009) Avaliação da concentração de metais traço (Zn, Co, Cr, As) em músculos de peixes de dois sistemas estuarinos (São Paulo, Brasil): Uma proposta para biomonitor de cromo". In: XIII Congreso Latino Americano de Ciencias del La Habana, Cuba. COLACMAR e VIII Congreso de Ciencias Del Mar, Mar Cuba, CD-Rom.

[45]. Landolt, M. L. and Kocan, R. M. (1983): Fish cell cytogenetics: A measure of the genotoxic effects of environmental pollutants. In Aquatic toxicology (J. O. Nriagu, ed.) 335-352. John Wiley and Sons Ins.

[46]. Lawrence R.C., Claudia B.G., Mary A., Tracy C., Mark S.M., Jon B. and Mark E.H. (2011) Reduced cytochrome P4501A activity and recovery from oxidative stress during subchronic Benzo[a]pyrene and Benzo[e]pyrene treatment of rainbow trout (Oncorhynchus mykiss). Toxicol Appl Pharmacol., 254(1): 1-7.

[47]. Leonardo S.K. and Elisabete de S.B. (2010) Cytogenetic disruption in fishes as bioindicator of the environmental quality in two estuarine system under different exposition to anthropogenic influences. Safety, health and environment world congress. July 25-28, Sao Paulo, Brazil.

[48]. Linda M.N.P., Derick C., Philip O.Y., Winston J. Q., Mordecai A.G. and Albert D. (2011) Characterization of polycyclic aromatic hydrocarbons present in smoked fish (Scomba japonicus) from Ghana. Advance Journal of Food Science and Technology, 3(5): 332-338.

[49]. Liu Y, Song L, Li X, Liu T 2002: The toxic effects of microcystin-LR on embryo-larval and juvenile development of loach, Misgurnus mizolepis Gunthe. Toxicon., 40: 395-399

[50]. Maccubbin (1994) Cytogenetic damage related to low levels of methyl mercury contamination in the Brazilian Amazon. An. Acad. Bras. Cienc., 72: 487-507.

[51]. Maples N.L. and Bain L.J. (2004) Trivalent chromium alters gene expression in the mummichog (Fundulus heteroclitus). Environ Tox Chem., 23(3):626-631.

[52]. Marcon A.E., Ferreira D.D.M., de-Moura M.F.V. et al. (2010) Genotoxic analysis in aquatic environment under influence of cyanobacteria, metal and radioactivity.Chemosphere, 81(6):773-780.

[53]. Mason AZ, Jenkins KD. (1995.) Metal detoxification in aquatic organisms. In: Tessier A, Turner DR, editors. Metal speciation and bioavailibility in aquatic ecosystems. New York, USA: Willey, p. 478-608. 
[54]. Matter, E.E.; ELserafy, S.S.; Zowail, M. E. M. \& Awwad, m.h. (1992): Genotoxic effect of carbamyl insecticide (sevin) on the grass carp Ctenopharygodan idella (VAL). Egypt. J. Histol., 15 (1): 9-17.

[55]. Matsumoto S.T. (2003) Efeitos Toxicos e Genotoxicos de Metais pesado, Especicamente do Cromo trivlente e Hexavalente. Monografia (Doutorado) Universidade Estadual Paulista. Sao Jose do Rio Preto- SP.

[56]. Matsumoto S.T., Janaina R., Mario S.M. and Maria A.M. (2005) Evaluation of the genotoxic potential due to the action of an effluent contaminated with chromium, by the Comet Assay in CHO-K1 Cultures. Caryologia, 58 (1): 40-46.

[57]. Natarajan, A. T. \& Obe, G. (1978): Molecular mechanisms involved in the protection of chromosomal aberrations. Mut. Res., 52: 137-149.

[58]. Obiakor M.O., Okonkwo J.C. and Nnabude P.C. (2010a) Micronucleus profile: An index of chromosomal aberrations in fresh water fish (Synodontis clarias and Tilapia nilotica). Online J. Anim. Feed Res., 1 (1): 41-46.

[59]. Obiakor M.O., Okonkwo J.C., Ezeonyejiaku C.D. and Ezenwelu C.O. (2010b) Genotoxicology: single and joint action of copper and zinc to Synodontis clarias and Tilapia nilotica. Journal of Applied Sciences and Environmental Management, 14:59-64.

[60]. Obiakor M.O., Ezeonyejiaku C.D., Ezenwelu C.O. and Ugochukwu G.C. (2010c) Aquatic genetic biomarkers of exposure and effect in catfish (Clarias gariepinus, Burchell, 1822). American-Eurasian Journal of Toxicological Sciences, 2 (4): $196-202$.

[61]. Obiakor M.O. (2010) Genotoxic evaluation of Anambra River using biomarker. M.Sc. Thesis, Nnamdi Azikiwe University, Awka, Anambra, Nigeria.

[62]. Olaifa F.E., Olaifa A.K., Adelaja A.A. and Owolabi A.G. (2004) Heavy metal contamination of Clarias gariepinus from lake and fish farm in Ibadan, Nigeria. African Journal of Biomedical Research, 7: 145-148.

[63]. Oliveira A.L. (2007) Avaliação da concentração de metais traço em tecidos de ariídeos e sua ictiofauna acompanhante de maior relevância ao consumo humano em dois sistemas estuarinos no estado de São Paulo. Relatório FAPESP Final. 40 pp.

[64]. Palhares D. and Grisolia C.K. (2002) Comparison between the Micronucleus Frequencies of kidney and gill erythrocytes in Tilapia fish, following Mitomycin-C treatment. Genetic and Molecular Biology, 25(3): 281-284.

[65]. Pantaleao S.M., Alcantara A.V., Alves J.P. and Spano M.A. (2006) The piscine micronucleus test to assess the impact of pollution on the Japaratuba river in Brazil. Environ. Mutagen, 47 (3): 219-24.

[66]. Park J.H.,Mangal D., Frey A. J., Harvey R. G., Blair I. A. and Penning R. M. (2009) Aryl hydrocarbon receptor facilitates DNA strand breaks and 8-oxo-2'- deoxyguanosine formation by the aldo-keto reductase product benzo[a]pyrene-7-8-dione. J. Biol. Chem., 284, 29725-29734.

[67]. Patel M.R., Scheffler B.E., Wang L. and Willett K.L. (2006) Effects of benzo(a)pyrene exposure on killifish (Fundulus heteroclitus) aromatase activities and mRNA. Aquat. Toxicol., 77: 267-278.

[68]. Pruski A.M. and Dixon D.R. (2002) Effects of cadmium on nuclear integrity and DNA repair efficiency in the gill cells of Mytilus edulis L. Aqua. Toxicol., 57: 127-137.

[69]. Raisuddin and Jha (2004) Micronuclei as an index of cytogenetic damage: past, present and future. Environmental and Molecular Mutagenesis, 18:277-291.

[70]. Retel, J.; Hoebee, B.; Braun, J. E. F.; Lutgerink, J.T.; Akker, E.; Wanamarta, A.H.; Joenje, H. and Lafleur, M.V. M.(1993): Mutational specific of oxidative DNA damage. Mut. Res., 299: 165-182.

[71]. Ricardo R.P., Osmindo R. and Cesar K.G. (2010) Toxicity and genotoxicity in Astyanax bimaculatus (Characidae) induced by microcystins from a bloom of Microcystis spp. Genetics and Molecular Biology, 33(4): 750-755

[72]. Salma Khan., Qayyum M.A. (2001) Effect of cadmium intoxication on blood serum protein of Clarias batrachus. Indian J. Applied and pure bio. Vol. 16 (2): 105-108.

[73]. Salma Khan., Qayyum M.A. (1992)Haematological response to mercury toxicity in Clarias batrachus. Ind.J.Z. Spect., Vol. 3, No. $1 \& 2(13-14)$.

[74]. Santodonato J., Howard P. and Basu D. (1981) Health and ecological assessment of polynuclear aromatic hydrocarbons, J. Environ. Pathol. Toxicol., 5: 1-36

[75]. Saotome K. and Hayashi M. (2003) Application of a sea urchin micronucleus assay to monitoring aquatic pollution: Influence of sample osmolarity. Mutagenesis, 18 (1): 73-6.

[76]. Scalon M.C.S., Rechenmacher C., Siebel A.M. et al. (2010) Evaluation of Sinos River water genotoxicity using the comet assay in fish. Brazilian Journal of Biology, 70: 1217-1222.

[77]. Shukla V., Dhankhar M., Prakash J. and Sastry K.V. (2007) Bioaccumulation of Zn, Cu and Cd in Channa punctatus. J of Environ Biol., 28 (2): 130-159.

[78]. Singh N.P., Mc coy T., Tice R.R. and Scheider E.L. (1988) A simple technique for quantization of low levels of DNA damage in individual cells. Exp. Cell Research, 175: 184-192.

[79]. Soares R.M., Magalhães V.F. and Azevedo S.M.F.O. (2004) Accumulation and depuration of microcystins (cyanobacterial laboratory conditions. Aquat Toxicol hepatotoxins) in Tilapia reandalli (Cichlidae) under., 70: 1-10.

[80]. Teles M., Pacheco M. and Santos MA. (2005) Physiological and genetic responses of European Eel (Anguilla anguilla L.) to shortterm chromium or copper exposure-influence of pre-exposure to a PAH-Like compound. Environ Toxicol., 20(1):92-99.

[81]. Toni P. Galindo and Lília M. Moreira (2009) Evaluation of genotoxicity using the micronucleus assay and nuclear abnormalities in the tropical sea fish Bathygobius soporator. Departamento de Biologia Geral, Instituto de Biologia, Universidade Federal da Bahia.Genetics and Molecular Biology, 32(2):394-398.

[82]. van der Oost, R., Beyer, J., Vermeulen, N.P.E., 2003. Fish bioaccumulation and biomarkers in environmental risk assessment: a review. Environ. Toxicol. Pharmacol. 13, 57-149.

[83]. Van Metre P.C., Mahler B.J. (2005) Trends in hydrophobic organic contaminants in urban and reference lake sediments across the United States, 1970-2001. Environ. Sci. Technol., 39: 5567-5574.

[84]. Venkatramreddy Velma and Paul B. Tchounwou (2010) Chromium induced biochemical, genotoxic and histopathologic effects in liver and kidney of Goldfish, Carassius auratus. Mutat Res., 698(1-2): 43-51.

[85]. Višnjić-Jeftić Z., Jarić I., Jovanovic L. et al. (2010) Heavy metal and trace element accumulation in muscle, liver and gills of the Pontic shad (Alosa immaculata Bennet 1835) from the Danube River (Serbia) Microchemical Journal, 95(2):341-344.

[86]. Vijver MG, Van Gestel CAM, Lanno RP, Van Straalen NM, Peijnenburg WJGM. (2004) Internalmetal sequestration and its ecotoxicological relevance: a review. Environ Sci Technol, 38:4705-12.

[87]. Vosyliene M.Z. and Jankaite A. (2006) Effect of heavy metal model mixture on rainbow trout biological parameters. Ekologija, 4: pp12-17.

[88]. Walton F., Ayllen G. and Garcia-Vazquez E. (1984) Induction of micronuclei and other abnormalities in European minnow, Phoximus phoximus and mobile, Poecilia lattipinna: an assessment of the fish micronucleus test. Mutat. Res., 467: 177-186.

[89]. Wirzinger G., Weltje L., Gercken J. and Sordyl H. (2007) "Genotoxic damage in field-collected three-spined sticklebacks (Gasterosteus aculeatus L.): A suitable biomonitoring tool?” Mutation Research, 628: 19-30. 
[90]. Wu Dong, Lu Wang, Cammi T., Brian E. S. and Kristine L. W. (2008) Benzo(a)pyrene decreases brain and ovarian aromatase mRNA expression in Fundulus heteroclitus. Aquat Toxicol., 88(4): 289-300.

[91]. Zhao M., Xie S., Zhu X., Yang Y., Gan N. and Song L. (2005) Effect of inclusion of blue-green algae meal on growth and accumulation of microcystins in gibel carp (Carassius auratus gibelio). J Appl Ichthyol, 22:72-78.

[92]. Zhao M., Xie S., Zhu X., Yang Y., Gan N. and Song L. (2006) Effect of dietary cyanobacteria on growth and accumulation of microcystins in Nile tilapia (Oreochromis niloticus). Aquaculture, 261: 960-966.

[93]. Zhu Y., Wang J., Bai Y. and Zhang R. (2004) Cadmium, chromium, and copper induced polychromatocyte micronuclei in Carp (Cyprinus carpio L.). Bull Environ Contamn Toxicol., 72: 78-86. 